\begin{tabular}{|c|c|}
\hline Title & Synthesis of sugar al cohols by hy drolytic hy drogenation of cellul ose over supported metal catalysts \\
\hline Author(s) & $\begin{array}{l}\text { Kobay ashi, Hirokazu; Ito, Y ukiko; Komanoya, Tasuku; Hosaka, Y uto; Dhepe, Paresh L.; Kasai, Koji; Hara, Kenji; } \\
\text { Fukuoka, A tsushi }\end{array}$ \\
\hline Citation & $\begin{array}{l}\text { Green Chemistry, 13(2), 326-333 } \\
\text { https://doi.org/10.1039/c0gc00666a }\end{array}$ \\
\hline Issue Date & 2011-02 \\
\hline Doc URL & http:/hdl.handle.net/2115/47418 \\
\hline Rights & Green Chem., 2011, 13, 326-333- Reproduced by permission of The Roy al Society of Chemistry (RSC) \\
\hline Type & article (author version) \\
\hline File Information & GC132_326-333.pdf \\
\hline
\end{tabular}

Instructions for use 


\title{
Synthesis of sugar alcohols by hydrolytic hydrogenation of cellulose over supported metal catalysts
}

\author{
Hirokazu Kobayashi, ${ }^{a}$ Yukiko Ito, ${ }^{a}$ Tasuku Komanoya, ${ }^{a, b}$ Yuto Hosaka,${ }^{a, b}$ Paresh L. Dhepe, ${ }^{a \neq}$ Koji Kasai, ${ }^{a}$ \\ Kenji Hara $^{a}$ and Atsushi Fukuoka*a
}

\author{
${ }_{5}$ Received (in $\left.X X X, X X X\right)$ Xth XXXXXXXXX 200X, Accepted Xth XXXXXXXXX 200X \\ First published on the web Xth $X X X X X X X X X 200 X$ \\ DOI: $10.1039 / b 000000 x$
}

Cellulose is converted into sorbitol and related sugar compounds over water-tolerant and durable carbon-supported Pt catalysts under aqueous hydrogenation conditions. Pre-treatment of cellulose

10 with ball-milling effectively reduces the crystallinity and particle size of cellulose, which results in high conversion of cellulose to sorbitol and mannitol. The selectivity of sorbitol increases by using $\mathrm{Cl}$-free metal precursors in the catalyst preparation as residual $\mathrm{Cl}$ on the catalysts promotes the side-reactions. The transformation of cellulose to sorbitol consists of the hydrolysis of cellulose to glucose via water-soluble oligosaccharides and the successive hydrogenation of glucose to sorbitol.

15 The hydrolysis of cellulose is the rate-determining step, and the Pt catalysts promote both the hydrolysis and the hydrogenation steps.

\section{Introduction}

Catalytic conversion of biomass to fuels and chemicals has attracted great attention as one of the future technologies for 20 inhibiting the global warming and for building up the lowcarbon society. ${ }^{1-3}$ In the photosynthesis reaction, huge amount of carbohydrates and oxygen are produced from carbon dioxide and water in plants using sunlight, and the plant biomass is a potentially abundant and renewable resource.

${ }_{25}$ Recently, the use of edible biomass for producing bioethanol has resulted in a competition between food and fuel, and this lesson has given us a consensus that we should use nonfood biomass as a precursor to fuels and chemicals. A typical nonfood biomass is lignocellulose in cell walls of plants.

30 Lignocellulose is composed of cellulose, hemicellulose and lignin, in which cellulose is a main component in woods. ${ }^{4}$ Therefore, the first target among nonfood biomass is cellulose. $^{5}$

Cellulose is a polymer of D-glucose, and starch is also a 35 polymer of glucose. They have different properties derived from the contrastive configuration of $\mathrm{C}-\mathrm{O}$ bonding in polymer chains. In amylose of starch, glucose units are linked by $\alpha$ 1,4-glycosidic bonds, while in cellulose they are joined together through $\beta$-1,4-glycosidic bonds (Fig. 1). Although 40 both polymers form crystalline structures with extensive intraand inter-molecular hydrogen bonds, those of amylose are relatively weak, and amylose is gelatinised in hot water. On the other hand, those of cellulose are remarkably more rigid and impenetrable even by hot-compressed water at $<590 \mathrm{~K} .{ }^{5,6}$

${ }_{45} \mathrm{As}$ a result, cellulose is greatly more resistant to depolymerisation than starch.

An extensive number of works have been devoted to the degradation of cellulose using enzymes, mineral acids and supercritical water, ${ }^{4,7-9}$ but these methods have drawbacks 50 such as slow reaction rate, difficult separation of products and catalysts, corrosion hazards, harsh conditions and generation
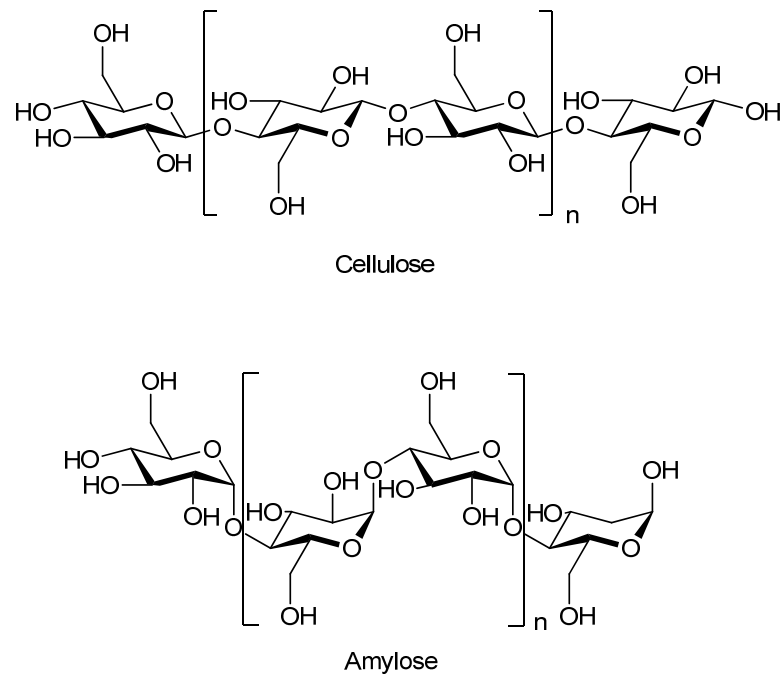

Fig. 1 Structures of cellulose and amylose.

of large amount of neutralisation waste. Heterogeneous 55 catalysis has advantages to overcome these drawbacks. We reported the first catalytic degradation of cellulose into sugar alcohols such as sorbitol and mannitol by supported metal catalysts under hydrogenolysis conditions. ${ }^{10}$ The sugar alcohols are useful precursors for the production of plastics 60 and pharmaceuticals. Since then the cellulose conversion by heterogeneous catalysis has rapidly developed for the synthesis of sugar alcohols, ${ }^{11}$ ethylene glycol ${ }^{12}$ and glucose. ${ }^{13}$ The hydrogenolysis reaction using supported metal catalysts has also been investigated on the conversion of lignin and its 65 model compounds. ${ }^{14}$ However, there still remains a need to improve the productivity in the synthesis of sugar alcohols. In this work, we studied the several factors controlling the reactivity of cellulose and the catalytic activity to discuss the detail of the reaction mechanism. 


\section{Experimental}

\section{Catalyst preparation}

Catalyst supports used in this study were as follows: carbon blacks BP2000 (Black Pearls 2000) and VULCAN XC72 were 5 supplied from Cabot. Activated carbon denoted as AC (Norit SX Ultra) was purchased from Aldrich. $\mathrm{Al}_{2} \mathrm{O}_{3}$ (JRC-ALO-2) and $\mathrm{ZrO}_{2}$ (JRC-ZRO-2) were obtained from Catalysis Society of Japan, and $\mathrm{TiO}_{2}(\mathrm{P}-25)$ from Degussa.

The supported metal catalysts prepared from ${ }_{10} \mathrm{Pt}\left(\mathrm{NH}_{3}\right)_{2}\left(\mathrm{NO}_{2}\right)_{2}, \mathrm{Pt}\left(\mathrm{NH}_{3}\right)_{4} \mathrm{Cl}_{2}, \mathrm{H}_{2} \mathrm{PtCl}_{6}, \mathrm{Ru}(\mathrm{NO})\left(\mathrm{NO}_{3}\right)_{3}$ and $\mathrm{RuCl}_{3}$ were denoted as $\mathrm{Pt}_{(\mathrm{N})}, \mathrm{Pt}_{(\mathrm{Cl}, \mathrm{N})}, \mathrm{Pt}_{(\mathrm{Cl})}, \mathrm{Ru}_{(\mathrm{N})}$ and $\mathrm{Ru}_{(\mathrm{Cl})}$, respectively. Other metal precursors used in this study were $\mathrm{Rh}\left(\mathrm{NO}_{3}\right)_{3}, \operatorname{Ir}(\mathrm{acac})_{3}$ and $\mathrm{Pd}\left(\mathrm{NO}_{3}\right)_{2}$. The typical catalyst, $\mathrm{Pt}_{(\mathrm{N})} / \mathrm{BP} 2000$ (Pt metal loading $2 \mathrm{wt} \%$ ) was prepared by a 15 conventional impregnation method as follows: $\mathrm{Pt}\left(\mathrm{NH}_{3}\right)_{2}\left(\mathrm{NO}_{2}\right)_{2}$ aq. $(0.202 \mathrm{mmol}$ in $5 \mathrm{~mL}$ of water $)$ was dropped into a mixture of carbon black BP2000 and water (20 $\mathrm{mL}$ ), and the mixture was stirred for $16 \mathrm{~h}$. After drying in vacuo, the solid was reduced with $\mathrm{H}_{2}\left(30 \mathrm{~mL} \mathrm{~min}^{-1}\right)$ at $673 \mathrm{~K}$

20 for $2 \mathrm{~h}$. In the preparation using oxide supports, the catalyst precursors were calcined in $\mathrm{O}_{2}$ flow $\left(30 \mathrm{~mL} \mathrm{~min}^{-1}\right.$ ) at $673 \mathrm{~K}$ before the $\mathrm{H}_{2}$-reduction, and in the impregnation of $\operatorname{Ir}(\mathrm{acac})_{3}$, $\mathrm{CH}_{2} \mathrm{Cl}_{2}$ was used as the solvent. The catalyst was analysed by using energy dispersive X-ray spectroscopy (EDX; Shimadzu

25 EDX-720), X-ray diffraction (XRD; Rigaku Miniflex, $\mathrm{Cu} \mathrm{K \alpha}$ radiation) and $\mathrm{CO}$ adsorption measurement (Quantachrome, ChemBET-3000).

\section{Pre-treatment of cellulose}

Cellulose was pre-treated using a ball-mill (Nitto Kagaku, 30 ANZ-51S). Cellulose (Merck, Avicel microcrystalline, $10 \mathrm{~g}$ ) was charged in a rotary ceramic container with $\mathrm{ZrO}_{2}$ balls (1 $\mathrm{kg}, 1 \mathrm{~cm}$ diameter). ${ }^{15}$ The container was rotated at a speed of $60 \mathrm{rpm}$ for 2 days (48 h) or 4 days (96 h). The ball-milled cellulose was characterised by XRD, cross polarisation/magic 35 angle spinning nuclear magnetic resonance (CP/MAS NMR; Bruker MSL-400, ${ }^{13} \mathrm{C} 100.6 \mathrm{MHz}$, rotation rate $4 \mathrm{kHz}$, external standard: glycine), optical microscope (Keyence VHX-1000) and laser diffraction (Nikkiso Microtrac MT3300EXII). The amount of physisorbed water was 40 determined by using a total organic carbon analyser (TOC; Shimadzu SSM-5000A) and weight loss in vacuum drying at $373 \mathrm{~K}$, and both experiments indicated that the water content was $5.0 \pm 1.0 \mathrm{wt} \%$ in the cellulose ball-milled for 2 days.

\section{Hydrogenation of cellulose}

${ }_{45}$ The conversion of cellulose under $\mathrm{H}_{2}$ pressure, denoted as hydrogenation of cellulose, was conducted in a stainless steel (SUS316) high-pressure reactor (OM Lab-Tech MMJ-100, $100 \mathrm{~mL}$ ). The milled cellulose (324 mg, $1.90 \mathrm{mmol}$ glucose units, containing $5.0 \mathrm{wt} \%$ physisorbed water), a supported Pt 50 catalyst (195 mg, Pt $20 \mu$ g-atom) and water $(40 \mathrm{~mL})$ were charged in the reactor (molar ratio of glucose unit/Pt $=95$ ), and then pressurised with $\mathrm{H}_{2}$ of 5.0 MPa. The reactor was heated to $463 \mathrm{~K}$ and maintained at the temperature for $24 \mathrm{~h}$ with stirring at $600 \mathrm{rpm}$. Products were separated by 55 centrifugation and decantation, and water-soluble products were analysed by high-performance liquid chromatography (HPLC; Shimadzu LC10-ATVP, refractive index detector). The columns used in this work were a Phenomenex Rezex RPM-Monosaccharide $\mathrm{Pb}++$ column $(\varnothing 7.8 \times 300 \mathrm{~mm}$, mobile

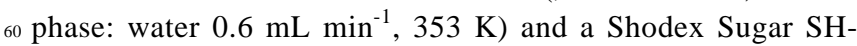
1011 column $\left(\varnothing 8 \times 300 \mathrm{~mm}\right.$, mobile phase: water $0.5 \mathrm{~mL} \mathrm{~min}^{-1}$, $323 \mathrm{~K})$.

\section{Results and discussion}

\section{Pre-treatment of cellulose}

${ }_{65}$ Cellulose has crystalline and amorphous parts in its structure. It is known that the amorphous region is first attacked by acids in the hydrolysis reaction ${ }^{16}$ as cellulose $I_{\alpha}$ crystal, which is a typical crystal phase of natural cellulose, has 8 hydrogen bonds for each glucose unit, while the number of those in 70 amorphous cellulose is 5.3. ${ }^{17}$ Likewise, it has been reported that amorphous cellulose is hydrolysed more rapidly than crystalline one by enzyme mixtures, ${ }^{18}$ although different cellulase enzymes have different preferential reaction sites on cellulose. ${ }^{19}$ The conversion of crystalline region into 75 amorphous one gives higher reactivity to cellulose. Various methods have been reported for the pre-treatment of cellulose

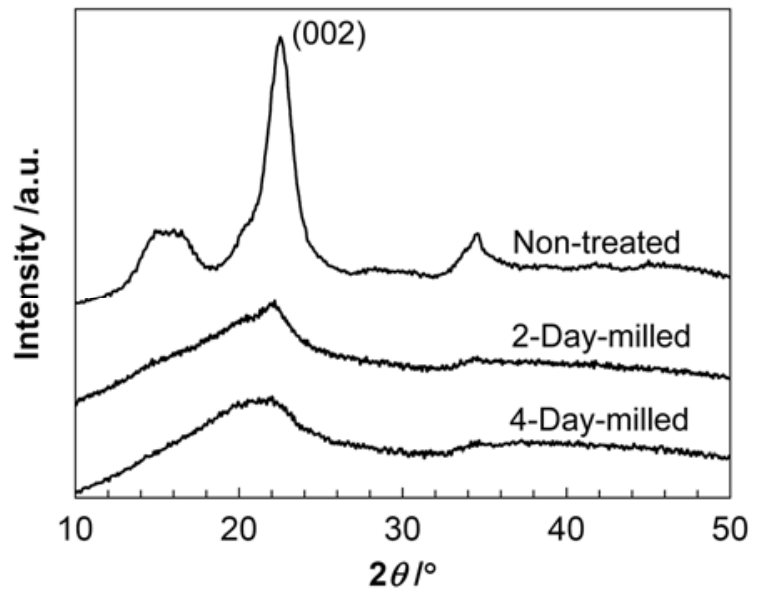

Fig. 2 XRD patterns of ball-milled cellulose.

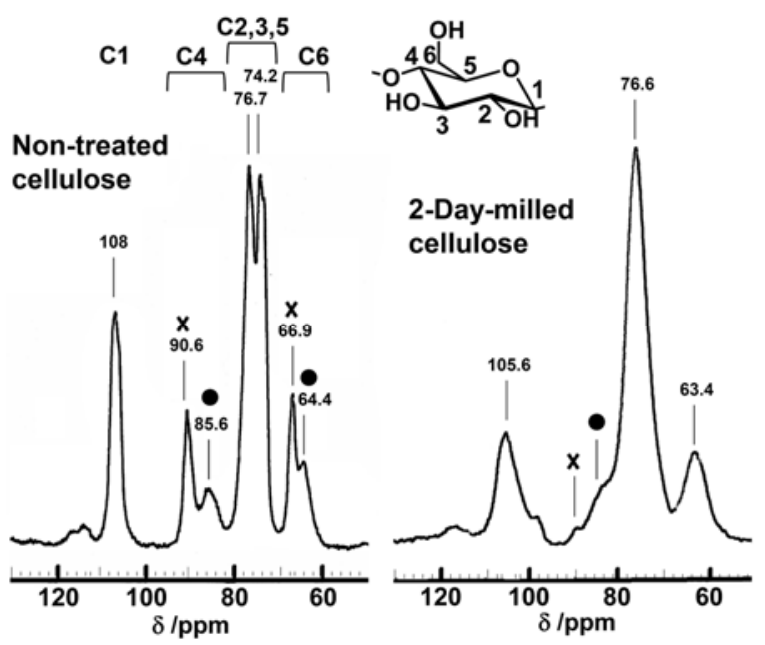

80 Fig. $3 \mathrm{CP} / \mathrm{MAS}{ }^{13} \mathrm{C}$ NMR of cellulose with or without the pre-treatment. $\mathrm{X}$ : crystalline part, filled circles: amorphous part. 

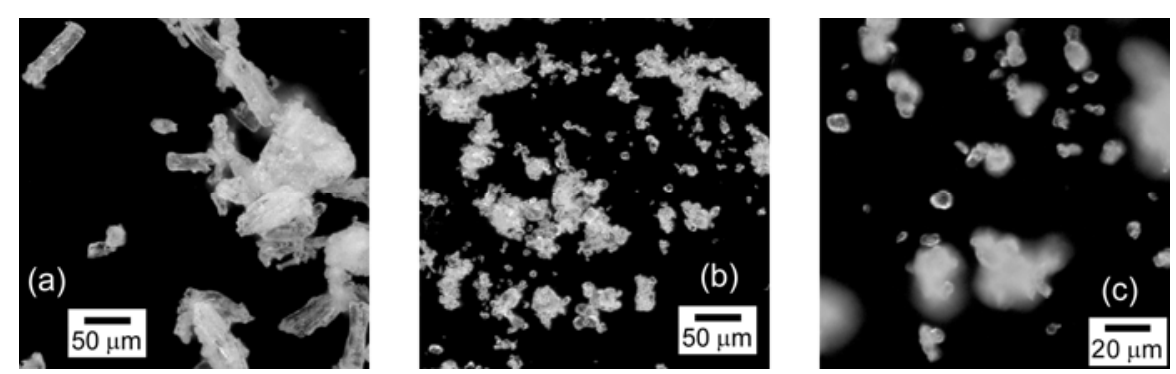

Fig. 4 Optical microscope images of (a) non-treated cellulose and (b, c) cellulose ball-milled for 2 days.

to reduce the crystallinity, and in our study ball-milling was selected for this purpose. Fig. 2 depicts the change of XRD diffractions of the cellulose after the pre-treatment. The intensity of (002) diffraction at $22.5^{\circ}$ clearly decreased by the treatment. The crystallinity index $(\mathrm{CrI})$ of each cellulose was $81 \%$ (non-treated), 22\% (2-day-milled) and 14\% (4-daymilled), estimated from the intensity difference of the (002) 10 diffraction and that of amorphous part. ${ }^{7 \mathrm{a}, 20}$ The CrI of cellulose significantly lowered during the pre-treatment for 2 days, but further milling gave no improvement. Thus, we compared the non-treated and 2-day-milled cellulose in the further characterisation.

15 The CrI can also be estimated by solid-state NMR. Fig. 3 exhibits CP/MAS ${ }^{13} \mathrm{C}$ NMR spectra of non-treated and 2-daymilled cellulose. C1-C6 carbons of pyranose ring resonate at 60-110 ppm, and the peaks at 82-92 ppm are assigned to C4. The C4-peak is allowed to be divided into two parts; the 20 lower-field peak is assigned to crystalline part and the higherfield one is derived from amorphous part. ${ }^{21}$ The $C r I$ calculated from the area ratio of the two peaks were $65 \%$ for the nontreated cellulose and $10 \%$ for the 2-day-milled cellulose. These $\mathrm{CrI}$ values are similar to those determined by XRD. 25 Accordingly, we confirmed that the crystallinity is effectively decreased by the ball-milling treatment.

Non-treated cellulose had various shapes as shown in Fig. 4(a). A typical dimension of needle-type one was ca. 20×50 $\mu \mathrm{m}$ and some parts were aggregated to make large secondary 30 particles. After the ball-milling for 2 days, cellulose turned smaller particles and their major part was aggregated [Fig.

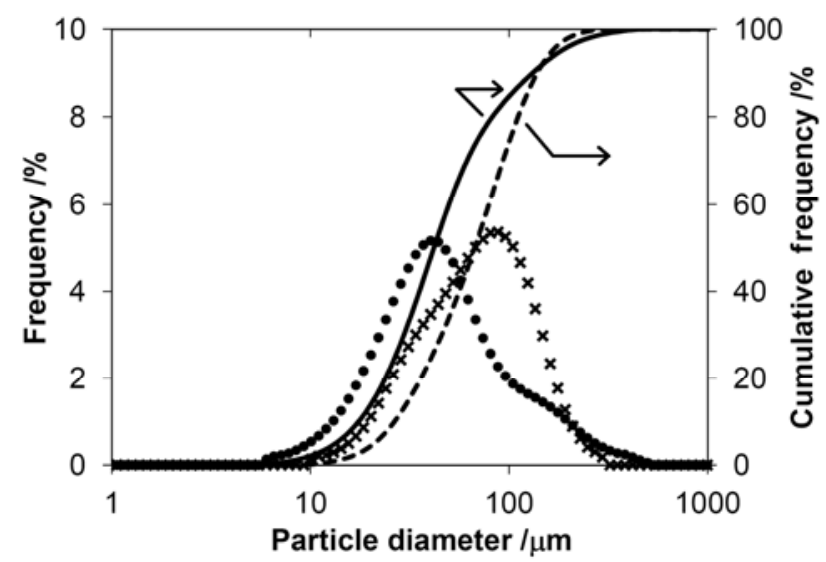

Fig. 5 Distribution of the particle diameter of cellulose in water. $\times$ and 35 dashed line: non-treated cellulose. Circles and solid line: 2-day-milled cellulose. 4(b)]. The primary particles with spherical or ellipsoidal structures in the range of 2-10 $\mu \mathrm{m}$ were observed in a higher magnification image [Fig. 4(c)]. The ball-milling treatment 40 changes both the particle size and the morphology.

Fig. 5 shows the distribution of the secondary particle diameter of cellulose in water. We assume that this analysis reflects the valid specific surface area of cellulose to be contacted with bulk solid catalysts. The diameter range of the 45 non-treated cellulose was $10-300 \mu \mathrm{m}$ and the median diameter (the diameter that the cumulative frequency is 50\%) was 67 $\mu \mathrm{m}$, which conforms to the particle diameter observed by the microscope. The distribution shifted lower and the median diameter diminished to $42 \mu \mathrm{m}$ by the pre-treatment for 2 days. ${ }_{50}$ Although the ball-milled cellulose is rather aggregated in water as the secondary particles are one-order of magnitude larger than the primary particles, the size is still smaller than that of non-treated cellulose.

From these results, it is demonstrated that the ball-milling 55 treatment decreases the $\mathrm{CrI}$ and the particle size of cellulose, thus enabling us to expect the improvement of the reactivity of cellulose.

\section{Catalytic conversion of cellulose}

Effect of the cellulose pre-treatment. The reactivity of ${ }_{60}$ cellulose with or without the pre-treatment was compared in the hydrogenation reaction. For this purpose, we used $\mathrm{Pt}_{(\mathrm{N})} / \mathrm{BP} 2000$ catalyst in this experiment because of the highest activity and good durability among the catalysts used in this work (see Optimisation of catalysts). Table 1 ${ }_{65}$ summarises the results of the hydrogenation under pressurised $\mathrm{H}_{2}$ conditions at $463 \mathrm{~K}$. The major products were sugar alcohols (sorbitol 39\% and mannitol 4\%, total 43\%, entry 7) and turnover number (TON) based on bulk $\mathrm{Pt}$ for the production of the sugar alcohols was 42 . The conversion of 70 the non-treated cellulose, determined by the weight loss in the reaction, was $66 \%$. Therefore, the selectivity for the sugar alcohols based on the converted cellulose was 66\%. Other identified products were 1,4-sorbitan, ethylene glycol, propylene glycol and glycerine. By ball-milling cellulose for 2 75 days, the conversion of cellulose was raised from $66 \%$ to $82 \%$, and the total yield of the sugar alcohols reached 58\% with $70 \%$ selectivity and 54 TON of Pt (entry 8). From these results, it is clearly shown that the reduction of the CrI and the particle size of cellulose by the ball-milling treatment ${ }_{80}$ enhances the reactivity of cellulose. No further improvement was observed for the 4-day-milled cellulose (60\% yield, entry 11) as suggested in the XRD measurement shown in Fig. 2. 
Table 1 Degradation of cellulose with $\mathrm{H}_{2}$ by supported metal catalysts. ${ }^{a}$

\begin{tabular}{|c|c|c|c|c|c|c|c|c|}
\hline \multirow[t]{2}{*}{ Entry } & \multirow[t]{2}{*}{ Catalyst } & \multicolumn{6}{|c|}{ Yield based on carbon /\% } & \multirow{2}{*}{$\begin{array}{c}\text { Cellulose } \\
\text { conversion }^{c} / \%\end{array}$} \\
\hline & & Sorbitol & Mannitol & $\begin{array}{c}\text { Sum of sorbitol } \\
\text { and mannitol }\end{array}$ & 1,4-Sorbitan & $\mathrm{C}_{2}-\mathrm{C}_{3}$ polyols $^{b}$ & Glucose & \\
\hline 1 & $\mathrm{Pt}_{(\mathrm{Cl})} / \mathrm{Al}_{2} \mathrm{O}_{3}$ & 31.6 & 6.6 & $38.2(43)$ & 15.8 & 8.3 & N.d. & 89.2 \\
\hline 2 & $\mathrm{Pt}_{(\mathrm{Cl}, \mathrm{N})} / \mathrm{Al}_{2} \mathrm{O}_{3}$ & 36.7 & 7.7 & 44.4 & 7.3 & 9.2 & N.d. & N.d. \\
\hline 3 & $\mathrm{Pt}_{(\mathrm{N})} / \mathrm{Al}_{2} \mathrm{O}_{3}$ & 46.0 & 4.8 & $50.8(70)$ & 3.0 & 0.8 & 0.2 & 72.3 \\
\hline $4^{d}$ & $\mathrm{Pt}_{(\mathrm{N})} / \mathrm{Al}_{2} \mathrm{O}_{3}$ & 35.2 & 8.2 & $43.4(55)$ & 1.2 & 0.6 & 0.5 & 78.9 \\
\hline $5^{d}$ & $\mathrm{Pt}_{(\mathrm{N})} / \mathrm{Al}_{2} \mathrm{O}_{3}$ & 45.1 & 8.1 & $53.2(53)$ & 1.5 & 2.0 & 0.7 & 101 \\
\hline $6^{e}$ & $\mathrm{Pt}_{(\mathrm{N})} / \mathrm{Al}_{2} \mathrm{O}_{3}$ & 37.6 & 9.6 & $47.2(48)$ & 13.6 & 3.7 & 0.7 & 98.0 \\
\hline $7^{f}$ & $\mathrm{Pt}_{(\mathrm{N})} / \mathrm{BP} 2000$ & 38.8 & 4.3 & $43.1(66)$ & 5.3 & 0.9 & 0 & 65.6 \\
\hline 8 & $\mathrm{Pt}_{(\mathrm{N})} / \mathrm{BP} 2000$ & 48.7 & 9.0 & 57.7 (70) & 1.9 & 1.5 & 0.1 & 81.9 \\
\hline $9^{d}$ & $\mathrm{Pt}_{(\mathrm{N})} / \mathrm{BP} 2000$ & 52.5 & 11.0 & $63.5(63)$ & 2.2 & 1.8 & 0.1 & 101 \\
\hline $10^{d}$ & $\mathrm{Pt}_{(\mathrm{N})} / \mathrm{BP} 2000$ & 52.7 & 12.1 & $64.8(64)$ & 3.0 & 2.0 & 0.1 & 101 \\
\hline $11^{g}$ & $\mathrm{Pt}_{(\mathrm{N})} / \mathrm{BP} 2000$ & 53.4 & 6.3 & 59.7 (65) & 10.4 & 1.0 & 0 & 92.3 \\
\hline 12 & $\mathrm{Pt}_{(\mathrm{N})} / \mathrm{XC72}$ & 44.3 & 11.1 & $55.4(63)$ & 1.9 & 1.4 & 0 & 87.8 \\
\hline $13^{d}$ & $\mathrm{Pt}_{(\mathrm{N})} / \mathrm{XC72}$ & 41.9 & 9.7 & $51.6(59)$ & 1.3 & 1.7 & 0 & 86.9 \\
\hline 14 & $\mathrm{Pt}_{(\mathrm{N})} / \mathrm{AC}$ & 16.8 & 5.3 & 22.1 (29) & 0 & 4.3 & 0.2 & 75.3 \\
\hline 15 & $\mathrm{Pt}_{(\mathrm{N})} / \mathrm{TiO}_{2}$ & 20.0 & 6.2 & 26.2 (33) & 1.3 & 1.6 & 0 & 78.8 \\
\hline 16 & $\mathrm{Pt}_{(\mathrm{N})} / \mathrm{ZrO}_{2}$ & 35.7 & 10.0 & 45.7 (62) & 2.7 & 1.7 & 0 & 74.1 \\
\hline $17^{d}$ & $\mathrm{Pt}_{(\mathrm{N})} / \mathrm{ZrO}_{2}$ & 36.1 & 9.1 & $45.2(56)$ & 1.9 & 0.7 & 0.2 & 80.6 \\
\hline 18 & $\mathrm{Ru}_{(\mathrm{Cl})} / \mathrm{Al}_{2} \mathrm{O}_{3}$ & 32.5 & 5.4 & $37.9(40)$ & 15.9 & 7.8 & N.d. & 95.5 \\
\hline 19 & $\mathrm{Ru}_{(\mathrm{N})} / \mathrm{Al}_{2} \mathrm{O}_{3}$ & 53.2 & 4.1 & $57.3(71)$ & 3.2 & 0.5 & 0.1 & 81.1 \\
\hline 20 & $\mathrm{Ru}_{(\mathrm{N})} / \mathrm{BP} 2000$ & 36.9 & 12.7 & 49.6 (57) & 1.9 & 0.5 & 0.1 & 86.4 \\
\hline 21 & $\mathrm{Rh} / \mathrm{BP} 2000$ & 5.2 & 3.2 & $8.4(10)$ & 0.3 & 6.2 & 0.5 & 86.8 \\
\hline 22 & Ir/BP2000 & 20.7 & 2.3 & $23.0(30)$ & 0.9 & 8.9 & 0.3 & 77.3 \\
\hline 23 & Pd/BP2000 & 0.3 & 0.2 & $0.5(1)$ & 0.1 & 2.2 & 0.3 & 76.6 \\
\hline
\end{tabular}

${ }^{a}$ Reaction conditions; cellulose $324 \mathrm{mg}$ (ball-milled for 2 days), catalyst $20 \mu$ g-atom-metal (metal 2 wt\%), water $40 \mathrm{~mL}$, reaction time $24 \mathrm{~h}$, $\mathrm{T}=463 \mathrm{~K}$, $P\left(\mathrm{H}_{2}\right)=5.0 \mathrm{MPa}$ at r.t. Selectivity based on the substrate conversion is shown in parenthesis. ${ }^{b}$ Sum of glycerine, propylene glycol and ethylene glycol. ${ }^{c}$ Based on the loss of weight during the reaction. ${ }^{d}$ The reuse experiment using the residue of the experiment of the previous entry number and fresh 5 cellulose of $324 \mathrm{mg}$. The conversion and yields are based on the fresh cellulose. ${ }^{e} \mathrm{HCl}$ of $59 \mu \mathrm{mol}$ was added. ${ }^{f}$ Cellulose was used without the pretreatment. ${ }^{g}$ 4-Day-milled cellulose was used.

Accordingly, we conclude that the 2-day-ball-milling is effective for the pre-treatment of cellulose under our catalytic conditions, and hereafter this pre-treatment is used as the 10 standard method.

Optimisation of catalysts. In the previous report, we used $\mathrm{Pt}_{(\mathrm{Cl})} / \mathrm{Al}_{2} \mathrm{O}_{3}$ and $\mathrm{Ru}_{(\mathrm{Cl})} / \mathrm{Al}_{2} \mathrm{O}_{3}$ catalysts for the hydrogenation of non-treated cellulose; however, the yields of the sugar 15 alcohols (sorbitol 25\%, mannitol 6\%) need to be improved. ${ }^{10}$ It is known that a small amount of $\mathrm{Cl}$ on supported metal catalysts may affect the hydrogenation activity, ${ }^{22}$ which prompted us to study the effect of $\mathrm{Cl}$ in catalyst precursors on the conversion of the pre-treated cellulose. In this work, we 20 used a Cl-free alumina support (JRC-ALO-2). $\mathrm{Pt}_{(\mathrm{Cl})} / \mathrm{Al}_{2} \mathrm{O}_{3}$ gave sorbitol of $32 \%$ and mannitol of $6.6 \%$, and the conversion of cellulose was $89 \%$ (Table 1, entry 1). The selectivity for the sugar alcohols based on the conversion was $43 \%$. Large amounts of 1,4-sorbitan and C-C and/or C-O 25 dissociated compounds such as ethylene glycol and propylene glycol were also generated (total 50\% yield). The yield of the sugar alcohols was improved to $44 \%$ by using a less $\mathrm{Cl}$ containing precursor $\left[\mathrm{Pt}\left(\mathrm{NH}_{3}\right)_{4} \mathrm{Cl}_{2}\right.$, entry 2] and to $51 \%$ by a Cl-free precursor [ $\mathrm{Pt}\left(\mathrm{NH}_{3}\right)_{2}\left(\mathrm{NO}_{2}\right)_{2}$, entry 3]. In the latter case,

30 1,4-sorbitan and other by-products significantly decreased, thereby raising the selectivity for the sugar alcohols up to $70 \%$ (entry 3). Ru catalysts also showed the same tendency; $\mathrm{Ru}_{(\mathrm{Cl})} / \mathrm{Al}_{2} \mathrm{O}_{3}$ prepared from $\mathrm{RuCl}_{3}$ produced the sugar alcohols in $38 \%$ yield and $40 \%$ selectivity (entry 18), whereas ${ }_{35} \mathrm{Ru}_{(\mathrm{N})} / \mathrm{Al}_{2} \mathrm{O}_{3}$ provided $57 \%$ yield and $71 \%$ selectivity (entry 19). These results indicate that $\mathrm{Cl}$-free precursors are suitable for the transformation of cellulose to sugar alcohols.

We performed EDX analysis of the Pt catalysts to determine the content of $\mathrm{Cl}$ (Fig. S1). Residual $\mathrm{Cl}$ in ${ }_{40} \mathrm{Pt}_{(\mathrm{Cl})} / \mathrm{Al}_{2} \mathrm{O}_{3}$ was $1.1 \mathrm{wt} \%$, but $\mathrm{Cl}$ in $\mathrm{Pt}_{(\mathrm{N})} / \mathrm{Al}_{2} \mathrm{O}_{3}$ was less than $0.01 \mathrm{wt} \%$. Fig. 6(b, c) shows the XRD patterns of these catalysts, and both catalysts showed the diffraction lines of $\gamma$ $\mathrm{Al}_{2} \mathrm{O}_{3}$ with no distinct peaks of Pt, indicating that Pt is highly dispersed. The mean diameters of $\mathrm{Pt}$ particles, determined 45 from CO-uptake, were $3.3 \mathrm{~nm}$ for $\mathrm{Pt}_{(\mathrm{N})} / \mathrm{Al}_{2} \mathrm{O}_{3}$ and $4.5 \mathrm{~nm}$ for $\mathrm{Pt}_{(\mathrm{Cl})} / \mathrm{Al}_{2} \mathrm{O}_{3}$, respectively, which represents that the structural properties of the catalysts are analogous. Therefore, a clear difference is the content of $\mathrm{Cl}$, and the residual $\mathrm{Cl}$ may adsorb on the metal surface to cause the $\mathrm{C}-\mathrm{C}$ and $\mathrm{C}-\mathrm{O}$ cleavage 50 reactions by inhibiting the selective hydrogenation sites and/or promoting the hydrogenolysis reactions. In addition, since the yield of 1,4-sorbitan, which is generated by the cyclodehydration of sorbitol, increased with the Cl-content in the catalyst precursors, another possible function of $\mathrm{Cl}$ is to 55 accelerate acid-catalysed reactions by the formation of $\mathrm{HCl}$ or $\mathrm{AlCl}_{\mathrm{x}}$ species. In fact, the addition of $\mathrm{HCl}(\mathrm{Cl} 1.1 \mathrm{wt} \%)$ to $\mathrm{Pt}_{(\mathrm{N})} / \mathrm{Al}_{2} \mathrm{O}_{3}$, which corresponded to the same $\mathrm{Cl}$ amount as that contained in $\mathrm{Pt}_{(\mathrm{Cl})} / \mathrm{Al}_{2} \mathrm{O}_{3}$ (entry 1 ), reduced the selectivity for the sugar alcohols (48\%) and increased the formation of by60 products like 1,4-sorbitan (entry 6). It is thus shown that the use of Cl-free precursors is one of the key factors to gain higher yields of sugar alcohols.

The durability of $\mathrm{Pt}_{(\mathrm{N})} / \mathrm{Al}_{2} \mathrm{O}_{3}$ catalyst was tested in reuse experiments; the catalyst was reused after drying at $383 \mathrm{~K}$ by 65 adding fresh cellulose of $324 \mathrm{mg}$, where the yields and the conversion were calculated based on the fresh cellulose. Total 


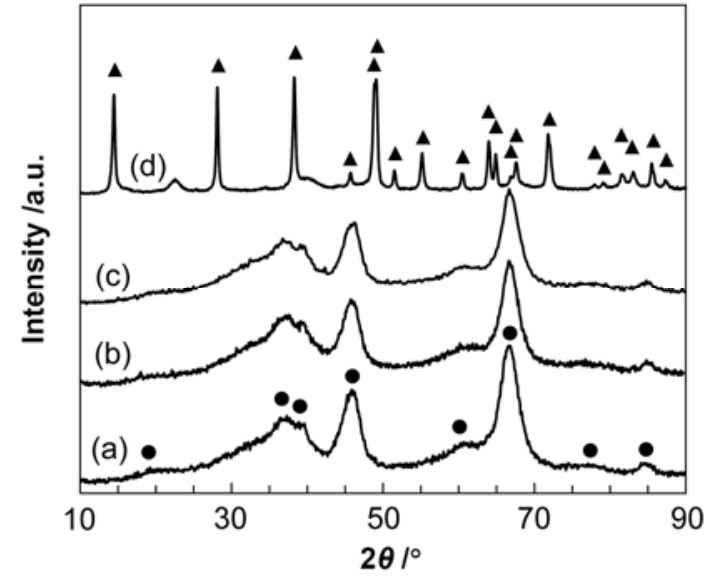

Fig. 6 XRD patterns of (a) $\mathrm{Al}_{2} \mathrm{O}_{3}$, (b) $\mathrm{Pt}_{(\mathrm{N})} / \mathrm{Al}_{2} \mathrm{O}_{3}$, (c) $\mathrm{Pt}_{(\mathrm{Cl})} / \mathrm{Al}_{2} \mathrm{O}_{3}$, and (d) $\mathrm{Pt}_{(\mathrm{N})} / \mathrm{Al}_{2} \mathrm{O}_{3}$ after the hydrogenation of cellulose. Circles: $\gamma-\mathrm{Al}_{2} \mathrm{O}_{3}$, triangles: boehmite.

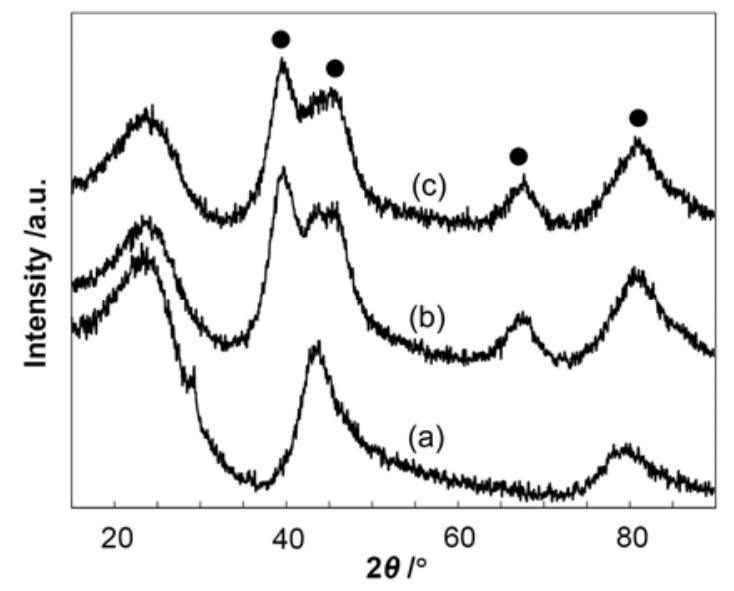

Fig. 7 XRD patterns of (a) BP2000, (b) $\mathrm{Pt}_{(\mathrm{N})} / \mathrm{BP} 2000$ catalyst before the hydrogenation of cellulose, and (c) $\mathrm{Pt}_{(\mathrm{N})} / \mathrm{BP} 2000$ after the reaction. Circles: Pt metal.

yields of the sugar alcohols in the reuse experiments were $1043 \%$ (2nd run, entry 4) and 53\% (3rd run, entry 5), which were comparable to that in the first run (51\%). The conversion of cellulose increased from $72 \%$ to $101 \%$ in the reuses because of the consumption of remaining cellulose in the previous runs. Therefore, the selectivity for the sugar alcohols 15 decreased from $70 \%$ to $53 \%$, indicating the reduction of the hydrogenation activity of the catalyst. In the XRD measurement of the spent catalyst after the first reaction, diffraction patterns of $\gamma-\mathrm{Al}_{2} \mathrm{O}_{3}$ completely disappeared, and sharp peaks of $\mathrm{AlO}(\mathrm{OH})$ (boehmite) were observed [Fig. 6(d)]. 20 The reduction of the catalytic activity is raised by the hydration of the support, perhaps causing burial of some $\mathrm{Pt}$ particles by the morphology change.

We carried out the screening of water-tolerant supports such as carbons, $\mathrm{TiO}_{2}$ and $\mathrm{ZrO}_{2}$ (entries 8-10, 12-17). Among 25 these supports, a carbon black BP2000 was found to provide the highest catalytic activity and good durability; the yields of the sugar alcohols in the reuse tests were $58 \%, 64 \%$ and $65 \%$, respectively, and the total TON of Pt was 175 (entries 8-10). Furthermore, no change was seen for the XRD patterns of ${ }_{30} \mathrm{Pt}_{(\mathrm{N})} / \mathrm{BP} 2000$ catalyst before and after the reaction [Fig. 7(b, c)], and the mean Pt diameters calculated with Scherrer's equation were both $2.6 \mathrm{~nm}$. These results indicate the watertolerant property of this catalyst. Other supports, XC72 and $\mathrm{ZrO}_{2}$ were less effective than BP2000, and AC and $\mathrm{TiO}_{2}$ were 35 not suitable as the support (entries 12-17). It is therefore concluded that BP2000 is a useful support for Pt to produce the sugar alcohols in water. BP2000-supported Ru, Rh, Ir and Pd catalysts were prepared from Cl-free precursors, but they were less active than the Pt catalyst (entries 20-23). This 40 finding led us to choose $\mathrm{Pt}_{(\mathrm{N})} / \mathrm{BP} 2000$ as the typical catalyst to study the kinetics of this reaction.

Mechanistic study using $\mathbf{P t}_{(\mathrm{N})} / \mathbf{B P 2 0 0 0}$ catalyst. Fig. 8(a) shows the time course of the hydrogenation of cellulose using ${ }_{45} \mathrm{Pt}_{(\mathrm{N})} / \mathrm{BP} 2000$ catalyst. The "reaction time" denotes the duration time at $463 \mathrm{~K}$ with excluding the heating and the cooling time (Fig. S2), thereby showing that the reaction slightly proceeded even at $0 \mathrm{~h}$. The amount of cellulose gradually decreased with the reaction time and reached $14 \%$ at $5016 \mathrm{~h}$. Although the conversion rate of cellulose is not expressed by a simple kinetic equation, we applied the firstorder approximation in Eq. 1 to evaluate the reaction rate, where $k_{\mathrm{C}}$ is the pseudo first-order rate constant. ${ }^{23} \mathrm{Eq} .1$ is transformed to an integral form as Eq. 2, where $\mathrm{X}$ is the 55 conversion of cellulose. The plot showed good linearity in the first $6 \mathrm{~h}$ (7-76\% conversion), and $k_{\mathrm{C}}$ was determined to be $0.21 \mathrm{~h}^{-1}$ [Fig. 8(b)].

$$
\begin{aligned}
& \mathrm{d}[\text { Cellulose }] / \mathrm{d} t=-k_{\mathrm{C}}[\text { Cellulose }] \\
& \ln \left([\text { Cellulose }] /[\text { Cellulose }]_{0}\right)=\ln (1-\mathrm{X})=-k_{\mathrm{C}} t
\end{aligned}
$$

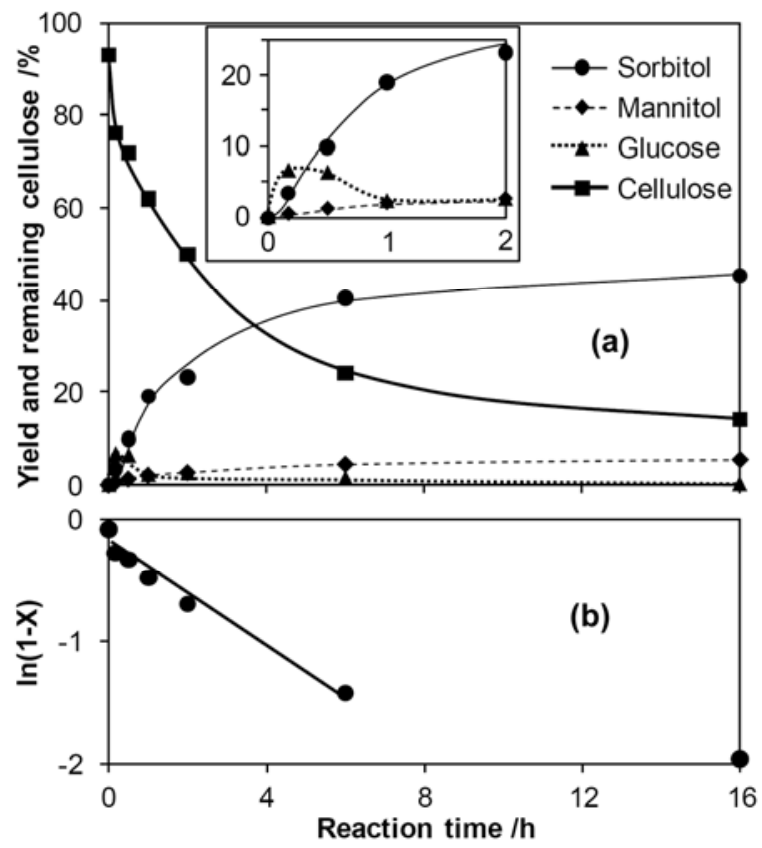

Fig. 8 (a) Time course of the hydrogenation of cellulose by $\mathrm{Pt}_{(\mathrm{N})} / \mathrm{BP} 2000$ catalyst and (b) the first-order plot of the remaining cellulose. The inset 65 shows the initial period of $2 \mathrm{~h}$. Reaction conditions: cellulose $324 \mathrm{mg}$ (1.9 mmol, 2-day-milled), $\mathrm{Pt}_{(\mathrm{N})} / \mathrm{BP} 2000195 \mathrm{mg}$ (Pt $20 \mu$ g-atom), water $40 \mathrm{~mL}$, $P\left(\mathrm{H}_{2}\right) 5.0 \mathrm{MPa}$ at r.t., $T=463 \mathrm{~K}$. Each plot is the result of each batch reaction with different reaction times. 

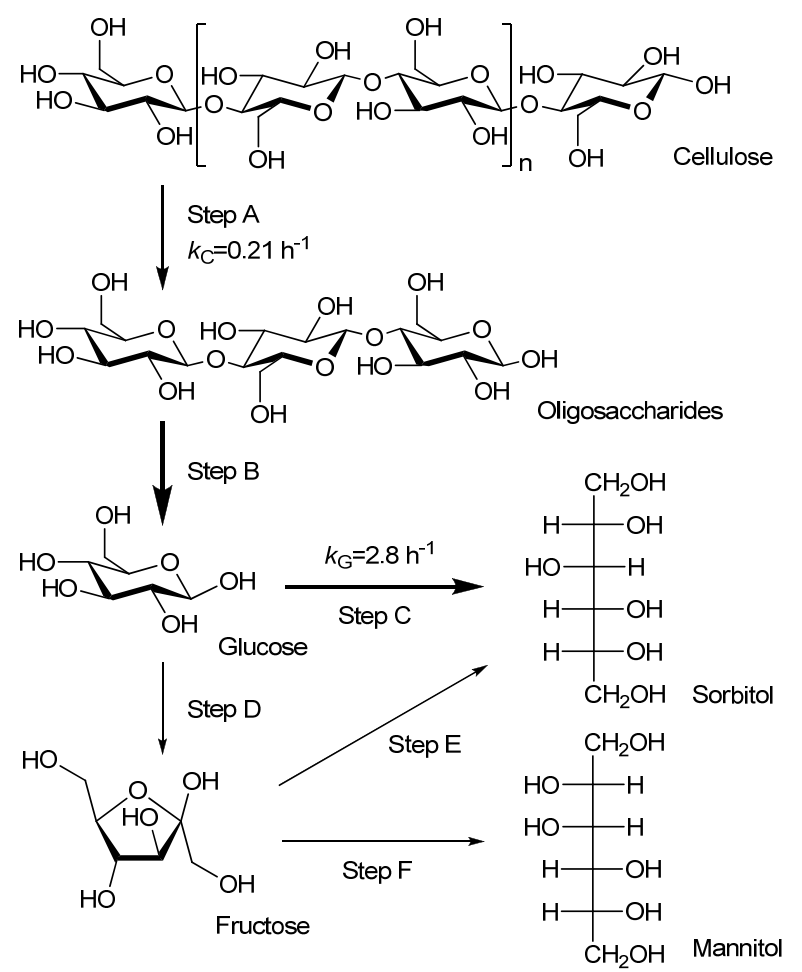

Scheme 1 Reaction pathway of the hydrogenation of cellulose using $\mathrm{Pt}_{(\mathrm{N})} / \mathrm{BP} 2000$ catalyst.

In focusing on the products, glucose was formed in $6.7 \%$ 5 yield at $0.2 \mathrm{~h}$ as a major product [Fig. 8(a) inset], whereas water-soluble oligosaccharides were negligible (less than $1 \%$ yield in total, data not shown). The yield of glucose decreased to $0.4 \%$ at $16 \mathrm{~h}$, while that of sorbitol smoothly increased after a short induction period and reached $45 \%$ at $16 \mathrm{~h}$. These facts 10 show that the conversion of cellulose to sorbitol consists of the hydrolysis of cellulose to glucose via water-soluble oligosaccharides, which is quickly hydrolysed to glucose, and the hydrogenation of glucose to sorbitol (Scheme 1 steps A-C). The maximum yield of glucose was only $6.7 \%$, indicating that 15 the hydrogenation of glucose is faster than the formation of glucose. To discuss the reaction rates of these steps quantitatively, we estimated the hydrogenation rate by using following hypothesis: glucose is hydrogenated by the Langmuir-Hinshelwood mechanism with the adsorption of 20 glucose and the dissociative adsorption of $\mathrm{H}_{2} \cdot{ }^{24}$ Assuming a pseudo first-order reaction (Eq. 3) because of the sufficiently low concentration of glucose $(<4 \mathrm{mM})$ and the large excess amount of $\mathrm{H}_{2}$, the rate constant $\left(k_{\mathrm{G}}\right)$ was calculated to be 2.8 $\mathrm{h}^{-1}$ by the curve fitting using the experimental results (Fig. S3), 25 which is 13 times higher than that of the hydrolysis step $(0.21$ $\mathrm{h}^{-1}$ ). From these results, it is concluded that the ratedetermining step is the hydrolysis of cellulose as expected.

$$
\mathrm{d}[\text { Sorbitol }] / \mathrm{d} t=k_{\mathrm{G}}[\text { Glucose }]
$$

A small amount of mannitol formed along with sorbitol. We also investigated the formation route of mannitol by assuming two possible pathways: (1) the hydrogenation of fructose and/or mannose and (2) the isomerisation of sorbitol.

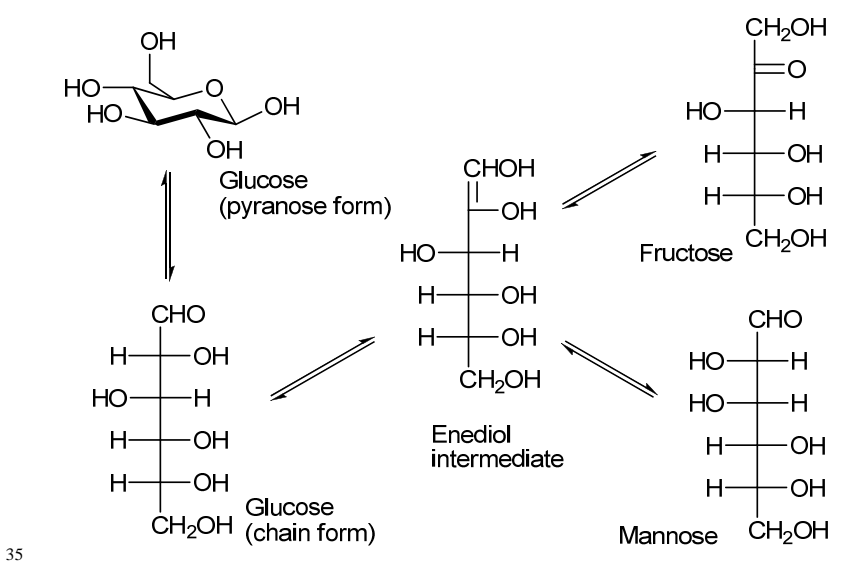

Scheme 2 Lobry de Bruyn and van Ekenstein transformation of glucose.

Regarding the first hypothesis, small amounts of fructose $(0.4 \%)$ and mannose $(0.3 \%)$ were detected at $0.5 \mathrm{~h}$ which were generated from glucose by Lobry de Bruyn and van Ekenstein 40 transformation $^{25}$ (Scheme 2), but they decreased with reaction time. In our experiments, the hydrogenation of fructose proceeded 2.2 times more rapidly than that of mannose, determined by an initial rate method, and produced sorbitol and mannitol in a ratio of $1: 1$ by using $\mathrm{Pt}_{(\mathrm{N})} / \mathrm{BP} 2000$ catalyst 45 (Scheme 1 steps E, F, Table S1). As to the second hypothesis, if the isomerisation of sorbitol to mannitol is the major pathway, the formation rate of mannitol is correlated with the concentration of sorbitol, but it is not the case in our reactions as shown in Fig. 8(a). Therefore, the main intermediate for 50 mannitol formation can be ascribed to fructose (steps D, F).

Fig. 9(a) represents the time course of the cellulose degradation with no catalyst under $\mathrm{H}_{2}$ pressure. The amount of cellulose smoothly decreased with the reaction time and the

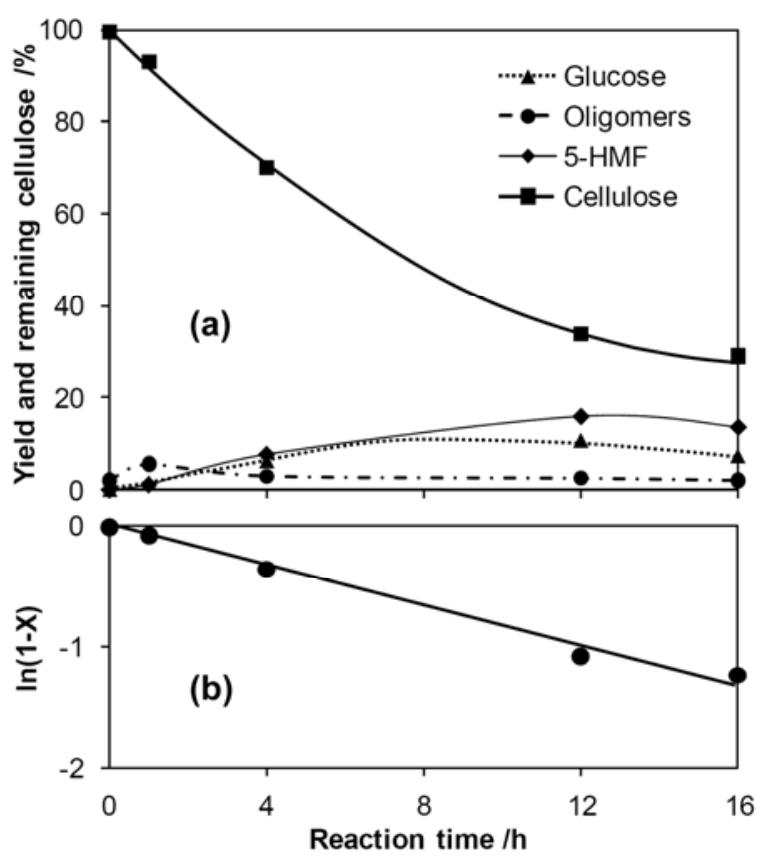

55 Fig. 9 (a) Time course of the degradation of cellulose under $\mathrm{H}_{2}$ pressure by no catalysts and (b) the first-order plot of the remaining cellulose. Reaction conditions: cellulose $324 \mathrm{mg}$ (1.9 mmol, 4-day-milled), water 40 $\mathrm{mL}, P\left(\mathrm{H}_{2}\right) 5.0 \mathrm{MPa}$ at r.t., $T=463 \mathrm{~K}$. Each plot is the result of each batch reaction with different reaction times. 
Table 2 Hydrolysis of cellulose under aerial conditions by $\mathrm{Pt}_{(\mathrm{N})} / \mathrm{BP} 2000$ catalyst. $^{a}$

\begin{tabular}{ccccc}
\hline \multirow{2}{*}{ Entry } & Catalyst & \multicolumn{2}{c}{ Yield based on carbon $/ \%$} & $\begin{array}{c}\text { Cellulose } \\
\text { conv. }^{c} / \%\end{array}$ \\
\cline { 3 - 4 } & Glucose & Oligosaccharides $^{b}$ & \\
\hline 24 & No catalyst & 4.6 & 14.1 & 24.2 \\
25 & BP2000 & 4.7 & 12.3 & 18.5 \\
26 & $\mathrm{Pt}_{(\mathrm{N})} / \mathrm{BP} 2000$ & 12.9 & 12.1 & 38.0
\end{tabular}

${ }^{a}$ Reaction conditions; cellulose $324 \mathrm{mg}$ (ball-milled for 4 days), catalyst $50 \mathrm{mg}$, water $40 \mathrm{~mL}, T=503 \mathrm{~K}$, reaction time $<1 \mathrm{~min}^{13 \mathrm{e}}$, under air. ${ }^{b}$

5 Dimer-octamer. ${ }^{c}$ Based on the loss of weight during the reaction.

unreacted quantity was $29 \%$ at $16 \mathrm{~h}$. It is proposed that $\mathrm{H}_{3} \mathrm{O}^{+}$ from water catalyses the hydrolysis of cellulose under these reaction conditions, ${ }^{11 \mathrm{a}, 11 \mathrm{c}, 26}$ because the ionic product of water $\left(\mathrm{p} K_{\mathrm{w}}\right)$ decreases with the temperature from 14.0 (298 K) to $1011.3(463 \mathrm{~K})$ as shown in Fig. S2. ${ }^{27}$ Therefore, higher temperatures have an advantage to accelerate the hydrolysis of cellulose in the reaction without catalysts in terms of the concentration of $\mathrm{H}_{3} \mathrm{O}^{+}$. The first-order plot of the remaining cellulose showed a linear line with a gradient of $0.082 \mathrm{~h}^{-1}$ [Fig.

${ }_{15}$ 9(b)], which was lower than the rate constant of the reaction using the Pt catalyst $\left(0.21 \mathrm{~h}^{-1}\right)$ in the conversion range of 10 $70 \%$ (Fig. 8). These results suggest that $\mathrm{Pt}_{(\mathrm{N})} / \mathrm{BP} 2000$ enhances the hydrolysis of cellulose; i.e., the supported Pt catalyst could hydrolyse the glycosidic bonds, and other 20 possibility might be that $\mathrm{Pt}$ generates protons by the heterolysis of $\mathrm{H}_{2} \cdot{ }^{10,11 \mathrm{c}}$ As shown in Table 2, $\mathrm{Pt}_{(\mathrm{N})} / \mathrm{BP} 2000$ catalyst gave a higher yield of glucose (13\%) than BP2000 (5\% yield) and no catalyst (5\% yield) in the hydrolysis of cellulose without $\mathrm{H}_{2}$ pressure under a rapid heating and 25 cooling conditions at $503 \mathrm{~K}^{28}$ This result also indicates that $\mathrm{Pt}_{(\mathrm{N})} / \mathrm{BP} 2000$ itself has the hydrolysis activity.

The reaction mixture without catalysts turned brownish with the reaction time, and black solids precipitated at $\geq 16 \mathrm{~h}$, which is in contrast to the colourless solution in the reactions 30 using the Pt catalyst. In the HPLC analysis of the solution, oligosaccharides were found as the principal products in the initial stage [Fig. 9(a), Scheme 3 Step A'], which is different from the reaction using the Pt catalyst. This result also

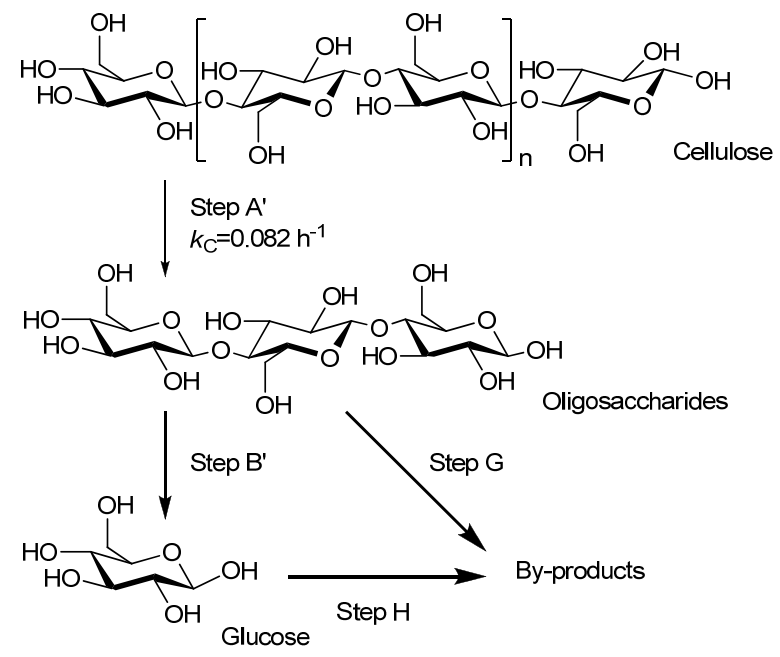

35 Scheme 3 Reaction pathway of the degradation of cellulose without catalysts. supports that the Pt catalyst hydrolyses the glycosidic bonds. After the formation of the oligosaccharides, glucose was generated with large amounts of various isomerisation and 40 dehydration by-products such as fructose, mannose, 5hydroxymethylfurfural (5-HMF), furfural, levoglucosan and organic acids, whose detail is shown in Table S2, because of high chemical reactivity of glucose and the reducing terminals of the oligosaccharides (steps B', G, H). Among the by${ }_{45}$ products, 5-HMF was obtained as a major component after passing $4 \mathrm{~h}$ in Fig. 9. No formation of the hydrogenated products shows that supported metal catalysts are essential for the reduction reactions.

\section{Conclusions}

50 To achieve the effective production of sorbitol and mannitol from cellulose, we studied the pre-treatment of cellulose and developed new catalysts for the hydrogenation of cellulose. The reduction of the $\mathrm{CrI}$ and the particle size of cellulose by ball-milling treatment for 2 days increased the reactivity and ${ }_{55}$ gave higher yields of the sugar alcohols with keeping the selectivity. Secondly, we found that $\mathrm{Pt}_{(\mathrm{N})}$ supported on a carbon black BP2000 is a selective and durable catalyst, compared to the previous $\mathrm{Pt}$ catalysts such as $\mathrm{Pt}_{(\mathrm{Cl})} / \mathrm{Al}_{2} \mathrm{O}_{3}$. A key point is the $\mathrm{Cl}$-free catalyst precursors as residual $\mathrm{Cl}$ on ${ }_{60}$ the catalysts derived from precursors induces side-reactions such as the $\mathrm{C}-\mathrm{C}$ cleavage and the dehydration. Another point is the water-tolerant supports which allow the reuse with good durability. The hydrogenation of cellulose consists of the hydrolysis of cellulose to glucose via oligosaccharides and 65 hydrogenation of glucose to sorbitol. The kinetic constant of each reaction was determined, which demonstrated that the Pt catalyst promotes both the hydrolysis and the hydrogenation steps and that the rate-determining step is the hydrolysis step.

\section{Acknowledgment}

70 This work was supported by Grant-in-Aid for Scientific Research (KAKENHI, 20226016) from the Japan Society for the Promotion of Science (JSPS).

\section{Notes and references}

${ }^{a}$ Catalysis Research Centre, Hokkaido University, Kita 21 Nishi 10, Kita75 ku, Sapporo 001-0021, Japan. Fax: 8111706 9139; E-mail: fukuoka@cat.hokudai.ac.jp

${ }^{b}$ Division of Chemical Sciences and Engineering, Graduate School of Chemical Sciences and Engineering, Kita 13 Nishi 8, Kita-ku, Sapporo 060-8628, Japan.

$80 †$ Electronic Supplementary Information (ESI) available: [hydrogenation of sugars, yields of products and time course of temperature in Fig. 9, EDX analyses, curve fitting of the cellulose conversion to determine $k_{\mathrm{G}}$ ]. See DOI: $10.1039 / \mathrm{b} 000000 \mathrm{x} /$

¥ Present address: National Chemical Laboratory, Pune 411008, India.

851 G. W. Huber, S. Iborra and A. Corma, Chem. Rev., 2006, 106, 40444098; A. Corma, S. Iborra and A. Velty, Chem. Rev., 2007, 107, 2411-2502.

2 B. Kamm, P. R. Gruber and M. Kamm, Biorefineries - Industrial Processes and Products, Wiley-VCH, Weinheim, 2006.

903 J. N. Chheda, G. W. Huber and J. A. Dumesic, Angew. Chem. Int. Ed., 2007, 46, 7164-7183.

4 Y. Sun and J. Cheng, Bioresour. Technol. 2002, 83, 1-11. 
5 D. Klemm, B. Heublein, H. -P. Fink and A. Bohn, Angew. Chem. Int. Ed., 2005, 44, 3358-3393.

6 S. Deguchi, K. Tsujii and K. Horikoshi, Chem. Commun., 2006, 3293-3295.

57 a) Y. -H. P. Zhang and L. R. Lynd, Biotechnol. Bioeng., 2004, 88, 797-824; b) Y. -H. P. Zhang, J. Cui, L. R. Lynd and L. R. Kuang, Biomacromolecules, 2006, 7, 644-648.

8 R. Rinaldi and F. Schüth, ChemSusChem, 2009, 2, 1096-1107; C. Li and Z. K. Zhao, Adv. Synth. Catal., 2007, 349, 1847-1850; K.

10 Shimizu, H. Furukawa, N. Kobayashi, Y. Itaya and A. Satsuma, Green Chem., 2009, 11, 1627-1632.

9 M. Sasaki, Z. Fang, Y. Fukushima, T. Adschiri and K. Arai, Ind. Eng. Chem. Res., 2000, 39, 2883-2890.

10 A. Fukuoka and P. L. Dhepe, Angew. Chem. Int. Ed., 2006, 45, 51615163; P. L. Dhepe and A. Fukuoka, ChemSusChem, 2008, 1, 969-975.

11 a) C. Luo, S. Wang and H. Liu, Angew. Chem. Int. Ed., 2007, 46, 7636-7639; b) W. Deng, X. Tan, W. Fang, Q. Zhang and Y. Wang, Catal. Lett., 2009, 133, 167-174; c) V. Jollet, F. Chambon, F. Rataboul, A. Cabiac, C. Pinel, E. Guillon and N. Essayem, Green Chem., 2009, 11, 2052-2060; d) S. Van de Vyver, J. Geboers, M. Dusselier, H. Schepers, T. Vosch, L. Zhang, G. Van Tendeloo, P. A. Jacobs and B. F. Sels, ChemSusChem, 2010, 3, 698-701; e) L. Ding, A. Wang, M. Zheng and T. Zhang, ChemSusChem, 2010, 3, 818-821.

12 N. Ji, T. Zhang, M. Zheng, A. Wang, H. Wang, X. Wang and J. G.

25 Chen, Angew. Chem. Int. Ed., 2008, 47, 8510-8513; M. Zheng, A. Wang, N. Ji, J. Pang, X. Wang and T. Zhang, ChemSusChem, 2010, 3 , 63-66; Y. Zhang, A. Wang and T. Zhang, Chem. Commun., 2010, 46, 862-864.

13 a) S. Suganuma, K. Nakajima, M. Kitano, D. Yamaguchi, H. Kato, S.

$30 \quad$ Hayashi and M. Hara, J. Am. Chem. Soc., 2008, 130, 12787-12793;

b) D. Yamaguchi, M. Kitano, S. Suganuma, K. Nakajima, H. Kato and M. Hara, J. Phys. Chem. C, 2009, 113, 3181-3188; c) A. Onda, T. Ochi and K. Yanagisawa, Green Chem., 2008, 10, 1033-1037; d) R. Rinaldi, R. Palkovits and F. Schüth, Angew. Chem. Int. Ed., 2008, 47,

35 8047-8050; e) H. Kobayashi, T. Komanoya, K. Hara and A. Fukuoka, ChemSusChem, 2010, 3, 440-443; f) S. Van de Vyver, L. Peng, J. Geboers, H. Schepers, F. de Clippel, C. J. Gommes, B. Goderis, P. A. Jacobs and B. F. Sels, Green Chem., 2010, 12, 1560-1563; g) K. Matsumoto, H. Kobayashi, K. Ikeda, T. Komanoya, A. Fukuoka and S. Taguchi, Bioresour. Technol., doi: 10.1016/j.biortech.2010.09.098.

14 N. Yan, C. Zhao, P. J. Dyson, C. Wang, L. -T. Liu and Y. Kou, ChemSusChem, 2008, 1, 626-629; C. Zhao, Y. Kou, A. A. Lemonidou, X. Li and J. A. Lercher, Angew. Chem. Int. Ed., 2009, 48, 3987-3990; J. Zakzeski, P. C. A. Bruijnincx, A. L. Jongerius and B. M. Weckhuysen, Chem. Rev., 2010, 110, 3552-3599.

15 H. Zhao, J. H. Kwak, Y. Wang, J. A. Franz, J. M. White and J. E. Holladay, Energy Fuels, 2006, 20, 807-811.

16 E. Kontturi and T. Vuorinen, Cellulose, 2009, 16, 65-74.

17 K. Mazeau and L. Heux, J. Phys. Chem. B, 2003, 107, 2394-2403.

5018 M. Hall, P. Bansal, J. H. Lee, M. J. Realff and A. S. Bommarius, FEBS J., 2010, 277, 1571-1582.

19 S. D. Mansfield, C. Mooney and J. N. Saddler, Biotechnol. Prog., 1999, 15, 804-816.

20 L. Segal, J. J. Creely, A. E. Martin and C. M. Conrad, Textile Res. J., 1959, 29, 786-794.

21 H. Kono, S. Yunoki, T. Shikano, M. Fujiwara, T. Erata and M. Takai, J. Am. Chem. Soc., 2002, 124,7506-7511.

22 T. Nakamura, M. Ohshima, H. Kurokawa and H. Miura, Chem. Lett., 2010, 39, 62-63.

6023 N. S. Mosier, C. M. Ladisch and M. R. Ladisch, Biotechnol. Bioeng., 2002, 79, 610-618.

24 E. Crezee, B. W. Hoffer, R. J. Berger, M. Makkee, F. Kapteijn and J. A. Moulijn, Appl. Catal. A:Gen., 2003, 251, 1-17.

25 J. C. Speck Jr., Adv. Carbohydr. Chem., 1958, 13, 63-103.

6526 T. Minowa, F. Zhen and T. Ogi, J. Supercrit. Fluids, 1998, 13, 253259.

27 W. L. Marshall and E.U. Franck, J. Phys. Chem. Ref. Data, 1981, 10, 295-304.

28 The detail of the hydrolysis method is described in reference 13e. 